\title{
GLUT-1 DEFICIENCY: FROM PATHOPHYSILOGY AND GENETICS TO ABROAD CLINICAL SPECTRUM
}

\author{
Arsov Todor \\ Epilepsy Research Centre, University of Melbourne, The Austin Hospital, Melbourne, Australia
}

Primljen/Received 11. 05. 2016. god.

Abstract: The classical GLUT-1 deficiency syndrome (GLUT-1 DS, De Vivo disease) was described over 2 decades ago as a metabolic encephalopathy characterized by developmental delay, secondary microcephaly paroxysmal neurological symptoms (epilepsy) and movement disorders. The biochemical parameters of this disease, used in diagnosis, are low levels of glucose in the cerebrospinal fluid, normal level of glucose in the blood and consequent low ratio of cerebrospinal fluid vs. blood glucose levels ( $<40-45 \%)$. So far, more than 200 cases of the classical GLUT-1 DS have been described in the literature. Genetic research demonstrated that this disease is caused by mutations in SLC2A1 gene coding for GLUT-1, a transporter of glucose across the blood brain barrier. Over the last few years the clinical spectrum of GLUT-1 deficiency was expanded to include other rare diseases such as paroxysmal exertional dyskinesia and early-onset absence epilepsy, but also some more common diseases such as idiopathic generalised epilepsy (1-2\%). GLUT-1 deficiency is an important pathophysiological basis of these diseases as early diagnosis (aided by DNA mutation testing) and treatment (ketogenic diet) could lead to improved disease outcomes.

Key words: GLUT-1 deficiency, De Vivo disease, SLC2A1, epilepsy, idiopathic generalised epilepsy, paroxysmal exertional dyskinesia, hypoglycorrachia.

\section{INTRODUCTION}

Human brain uses glucose as a principle fuel for its function. It is estimated that on average an adult human brain uses at least $20-25 \%$ (up to $80 \%$ in infants) of the total body glucose supply (1-7). Glucose molecule does not diffuse freely across the blood-brain barrier and GLUT-1, an uniporter glucose transporter, allows facilitated glucose transport across the blood-brain (and other blood-tissue) barriers $(1,2)$.
Prihvaćen/Accepted 12.06. 2016. god.

GLUT-1 is encoded by SLC2A1 gene (solute carrier family 2 , facilitated glucose transporter member 1 , OMIM 138140) located on the short arm of chromosome $1 \mathrm{p} 34.2,35 \mathrm{~kb}$ long comprising 10 exons (1). It is highly conserved, with a $98 \%$ homology between human and mouse GLUT-1 sequence and also $40 \%$ homology to other GLUT transporters (1-6). GLUT-1 is constitutively expressed in most tissues and cells, with particularly high level of expression in brain microvessels and astroglia as well as the erythrocyte membrane (1-4). It consists of intracellular C- and N- terminal domain and 12 hydrophobic domains, each of which is forming a transmembrane helix (1-4). GLUT-1 transporter is hypothesised to oscillate between two conformations: "open" conformation when glucose level in the target tissue/cell is low allowing glucose to be transported across the cell membrane and "closed" conformation acquired by GLUT-1 once the level of glucose have increased to meet the metabolic need.

\section{THE CLASSICAL DE VIVO GLUT-1 DEFICIENCY SYNDROME (GLUT-1 DS)}

Human pathology associated with GLUT-1 was first described by Darryl De Vivo, who more than 3 decades ago reported two cases of GLUT-1 deficiency syndrome (GLUT-1 DS) (3-7). This syndrome was characterized clinically by infantile seizures, developmental delay and acquired microcephaly, accompanied by laboratory findings of low cerebrospinal fluid (CSF) glucose - hypoglycorrhachia, normal plasma glucose levels, low CSF-to-plasma glucose ratio and low-to-normal cerebrospinal lactate levels (3-7).

Within the following decade the same group demonstrated that the observed GLUT-1 DS phenotype is due to mutations in the gene encoding GLUT1 -SLC2A1 (5). The mutations identified in this first report of the molecular genetic basis of GLUT-1 DS aro- 
se "de novo" and were either larger deletions (GLUT-1 hemizygosity) or point mutations that generate truncated non-functional GLUT-1 likely to be degraded before reaching the erythrocyte membrane. The pathogenicity of these SLC2A1 mutations was confirmed by showing approximately $50 \%$ reduction GLUT- 1 protein expression and $30-50 \%$ reduction in glucose uptake by patient's erythrocytes (5). Following this initial report, a number of studies around the world reported findings of SLC2A1 mutations in GLUT-1 DS.

The animal model of GLUT-1 DS provided further evidence that mutations reducing GLUT-1 transport function are responsible for GLUT-1 DS: heterozygous GLUT-1 knock-out mice recapitulated the human GLUT-1 DS phenotype (microcephaly, epileptiform discharges on EEG, impaired motor activity and incoordination) and the homozygous GLUT-1 loss was lethal in the early embryonic development of the GLUT-1 null mice $(3,8)$.

Since the first reports of GLUT-1 DS and its molecular genetic basis, more than 200 cases of GLUT-1 DS have been published, providing further insight in both the clinical and molecular genetic features of this rare syndrome (1-7). As the number of reported GLUT-1 DS patients increased, the clinical phenotype of the syndrome became more variable (for example varying degree of developmental delay and intellectual deficit, various severity and type of seizures), but was generally consistent with a major metabolic encephalopathy characterized by developmental delay, microcephaly, seizures and often included complex movement disorders, ataxia and/or spasticity $(5,6,7)$.

Thus, GLUT-1 deficiency syndrome was established as a rare, monogenic, autosomal dominant disease, most frequently caused by sporadic and "de novo" mutations in SLC2A1. These mutations inactivate one SLC2A1 allele (deletions and truncating mutation, or point mutations affecting amino acid residues critical for normal structure and function of GLUT-1, affecting various regions and amino acid residues within the GLUT-1 molecule), and this leads to severe functional impairment of GLUT-1 glucose transport capacity and reduced glucose transport across the blood-brain barrier (3-7). The established diagnostic criteria for GLUT-1 DS included clinical findings consistent with metabolic encephalopathy (microcephaly, developmental delay often accompanies by paroxysmal symptoms such as seizures and movement disorders) and confirmed by low CSF glucose levels (hypoglycorrhachia, SCF glucose $<2.2 \mathrm{mmol} / \mathrm{L}$ ) with normal plasma glucose levels and low ratio of blood-to-cerebrospinal fluid glucose (usually< 40-45\%) (1-7). Ketogenic diet provided therapeutic benefits of varying degree for the diagnosed GLUT-1 DS patients, being more successful in control- ling the paroxysmal symptoms then the cognitive function $(20,21)$.

\section{EXPANDING THE GLUT-1 DS SPECTRUM, PAROXYSMAL EXERTIONAL DYSKINESIA (PED)}

More recently, the clinical spectrum of GLUT-1 DS was expanded to include paroxysmal exertional dyskinesia. PED is an extremely rare type of paroxysmal dyskinesia characterized by involuntary, sudden, dystonic movements, including repetitive twisting motions and painful posturing. The attacks are usually triggered by exercise (or other physical exertion), usually affect the part of the body being exercised and last from a few minutes to an hour (9-12). PED can exist as an isolated condition or it can be accompanied by additional neurological features, such as epilepsy (10). A few recent studies implicated GLUT-1 deficiency as pathophysiological basis for PED and broadened the clinical spectrum of GLUT-1 deficiency (10-12).

A genetic linkage analysis of a five generation Belgian family segregating PED and epilepsy pointed to SLC2A1 as a candidate gene for the observed complex phenotype (10). Indeed, SLC2A1 mutations were found in this and three additional nuclear families segregating similar clinical phenotypes including PED. The identified SLC2A1 mutations were heterozygous missense mutations and frameshift mutations that were not found in normal healthy controls. Affected individuals had reduced CSF-to-plasma glucose ratios and the mutated GLUT-1 molecules were found to have reduced capacity to transport glucose in vitro, both findings establishing the pathogenicity of the identified SLC2A1 mutations in these PED patients (10). Interestingly, while most of the affected individuals in this study displayed both PED and epilepsy, there were also cases with PED or epilepsy phenotypes only. The seizure types were absences, generalized tonic-clinic seizures, complex and simple partial seizures and/or myoclonic seizures. In one family the mutation arose "de novo" and in the other 3 the mutations were inherited (10).

Another family with a complex clinical phenotype, including PED, epilepsy, intellectual deficit and haemolytic anemia, was shown to segregate a 4 amino acids deletion (Q282_S285del) affecting the $7^{\text {th }}$ transmembrane helix of GLUT-1 (11). Interestingly, the complex phenotype in this family included hemolytic anemia, characterized by increased $\mathrm{Na}+$ and decreased $\mathrm{K}+$ levels in patients' erythrocytes, suggesting a "cation leak" through the mutant GLUT-1 as a likely pathophysiological mechanism underlying the hemolytic anemia phenotype. This study reported SLC2A1 mutations in 2 out of 4 additional families with PED (11). 
Following these two initial reports linking PED to GLUT-1 deficiency, a number of research groups published similar findings of SLC2A1 mutations in familial, but also sporadic cases of PED with one study reporting SLC2A1 mutations in 2/10 sporadic cases of PED (12).

A recent literature review identified 41 patients with PED due to GLUT-1 deficiency and found that most cases had onset in early childhood (mean age at onset 8.6 years) with varying frequency of attacks (from sever per day to 1 per month). Attacks were mostly choreo-dystonic and lasted between 15 and 40 min. Concomitant disturbances included epilepsy, learning difficulties, ataxia, pyramidal signs and hemolytic anemia (13).

\section{EXPANDING THE GLUT-1 DS CLINICAL SPECTRUM: EPILEPSY SYNDROMES, EARLY-ONSET ABSENCE EPILEPSY (EOAE), IDIOPATHIC GENERALISED EPILEPSY (IGE)}

With the exception of rare families segregating monogenic Mendelian epilepsy syndromes (mostly due to mutations in genes coding for ion channels, such as SCN1A), epilepsy is considered to be a common complex disease whose ethology includes both, a complex interaction between certain environmental factors and the genetic make-up as well as a complex interaction of a few to many genes with minor genetic contribution (14). In familial forms of epilepsy, the pedigree analyses usually confirm complex patterns of inheritance.

Given the presence of various epilepsy syndromes (including absence epilepsy) in the reported cases of GLUT-1 DS (both the classical De Vivo syndrome and/or milder PED variants), we and others looked for SLC2A1 mutations in various forms of epilepsy. An initial study looked for mutations in SLC2A1 in 34 patients with early-onset absence epilepsy (age of onset under 4 years of age) and found mutations in $12 \%$ of patients (4/34, 2 "de novo", 2 familial), indicating GLUT1 deficiency may be the cause of a significant proportion of early-onset absence epilepsy (15).

A confirmatory cohort included 55 cases of early-onset absence epilepsy (and 500 controls) found that 7 patients (13\%) had mutations in SLC2A1 (5 missense, 2 deletions) and confirmed that about 1 in 10 cases of early-onset absence epilepsy are due to mutations in SLC2A1 (16). Importantly, this study also showed that while the diagnostic criteria of the classical De Vivo GLUT-1 DS includes CSF glucose levels $<2.2 \mathrm{mmol} / \mathrm{L}$ and CSF-to-blood glucose ratio of $<50 \%$, the milder GLUT-1 deficiency cases, presenting clinically as EOAE or other "midler" phenotype, may have both higher (and even normal) levels of CSF glucose and also CSF-toblood glucose ratio of above $50 \%$ (16). The high frequency of SLC2A1 mutations in early-onset absence epilepsy also raises the question for routine use of genetic testing in cases with early onset epilepsy (especially onset under the age of 4 years and absence type epilepsy).

We also tested the hypothesis that GLUT-1 deficiency clinical spectrum may include not just rare conditions (PED, early-onset absence epilepsy), but also a more common condition such as idiopathic generalised epilepsy, traditionally considered to be a complex genetic disease (the lifetime incidence of epilepsy is $3 \%$, with IGE accounting for $25 \%$ of all epilepsy cases) (12-19). To assess the contribution of GLUT-1 deficiency and SLC2A1 mutations in idiopathic generalised epilepsy, we screened for SLC2A1 mutations in 504 patients with IGE and found that 7 patients (1.4\%) had mutations, functionally validated to reduce the transport function of mutant GLUT-1 in vitro (17). All of the affected probands fulfilled the diagnostic criteria for idiopathic generalised epilepsy and had normal development and intellect, some of the families co-segregated PED (17).

Another Swiss study found SLC2A1 mutations in $2.1 \%(2 / 93)$ of IGE cases (18). This study also reported combined results on the frequency of SLC2A1 mutations in various forms of epilepsy form the published literature: overall SLC2A1 frequency in epilepsy was $29 / 1110$ or $2.9 \%$ (combined 7 studies), the highest rate being in EOAE - 5.6\% (4 studies including 303 patients) (18).

The finding that around $1-2 \%$ of IGE is actually monogenic disease (GLUT-1 IGE) is quite intriguing as it directly challenges the standing concept of the complex genetic architecture of epilepsies in general and IGE in particular. The autosomal dominant Mendelian inheritance pattern of GLUT-1 IGE may be obscured in many cases due to the incomplete penetrance and "de novo" nature of SLC2A1 mutations in many cases (17). The findings establishing SLC2A1 mutations in the genetic architecture of IGE and GLUT-1 deficiency as an underlying pathophysiology of IGE are important as they may have implications both for diagnosis and treatment of these patients.

\section{CONCLUSIONS: EARLY DIAGNOSIS AND TREATMENT CONSIDERATIONS}

While glucose is the primary (and perhaps preferred) source of energy for the brain (either as glucose or in the form of lactate), the brain can also switch to alternative sources of energy such as ketone bodies, produced in the course of a ketogenic diet $(1,3,20,21)$. This therapeutic approach has been used in the treatment of medication-refractory seizures for many years 
with varying success. The theoretical concept that by-passes the defective glucose transport across the blood-brain barrier by offering the brain an alternative source of energy (ketone bodies) was proven therapeutically beneficial in GLUT-1 DS and over the decades the ketogenic diet become the "golden standard" in the treatment of this condition $(6,20,21)$.

In patients with GLUT-1 DS ketogenic diet has been shown to be particularly beneficial in controlling seizures (reported cased of refractory seizures responding very well to ketogenic diet) and abnormal motions, including PED (refractory PED severely limiting walking responding to this treatment within days), without the need for anticonvulsants $(20,21)$. Although the cognitive function is least responsive to ketogenic diet, reports suggest that patients that started earlier with ketogenic diet have overall better outcomes $(6,20,21)$.

Historically, the diagnostic approach included glucose testing in blood and CSF (low levels $<2.2$ $\mathrm{mmol} / \mathrm{L}$ and/or CSF-to-blood ratio $<40-45 \%$ was considered consistent with the diagnosis) when there was a clinical suspicion of this extremely rare and under-recognised condition (the classical De Vivo GLUT-1 DS) - and this led to delays in diagnosis or in many cases perhaps non-diagnosis. Recent developments in understanding GLUT-1 deficiency and the associated clinical spectrum as well as the accessibility and affordability of the genetic testing (which may yield positive results in $25-50 \%$ of selected cohorts) makes the early diagnosis and early treatment a realistic prospect. Early seizures (often within the first 6 months), abnormal eye/other movements and paroxysmal neurological phenomena, acquired microcephaly, accompanied by normal blood glucose levels and low CSF level, including low CSF-to-blood ratio $(<50 \%$ in cases with high clinical suspicion, $<60 \%$ in cases with low clinical suspicion, caution: milder GLUT-1 DS phenotypes may have low-normal to normal CSF) should raise the suspicion of GLUT-1 DS and prompt genetic testing (22).
The expanding clinical spectrum of GLUT-1 deficiency is in the spotlight for a few reasons. Firstly, while GLUT-1 deficiency was initially considered to be a rare genetic condition (GLUT-1 DS) it is now clear that this pathophysiological mechanism underlies a few more common clinical entities, such as PED, early-onset absence epilepsy, idiopathic generalised epilepsy and perhaps others (1-16). The classical and rare De Vivo GLUT-1 DS comprises the severe end of the GLUT-1 deficiency spectrum that includes patients with a significant reduction in GLUT-1 glucose transport function (40-75\%), whereas the non-classical milder forms (intermittent neurologic phenomena, such as PED, epilepsy) arise when mutations lead to milder reduction in glucose transport function (20-35\%) (1). Secondly, ketogenic diet seems to be effective in treating all clinical conditions with GLUT-1 deficiency as an underlying pathophysiological mechanism $(6,20,21)$. The increased awareness of these conditions among pediatricians and neurologists and relaxed and improved diagnostic criteria including genetics testing may lead to earlier diagnosis, earlier treatment and better outcomes. Lastly, genetic research in rare disorders may shine light on the genetic architecture of more common and traditionally considered complex genetic disorders $(16,17)$.
Abbreviations
IGE - idiopathic generalised epilepsy
EOAE - early-onset absence epilepsy
PED - paroxysmal exertional dyskinesia
GLUT-1 (SLC2A1) - glucose transporter 1, sol- ute carrier family 2, facilitated glucose transporter
GLUT-1 DS - GLUT-1 deficiency syndrome
CSF - cerebrospinal fluid member 1

\section{CONFLICT OF INTEREST}

The author has no conflict of interest to disclose.

\title{
Sažetak
}

\section{GLUT-1 DEFICIT: OD PATOFIZIOLOGIJE I GENETIKE DO ŠIROKOG KLINIČKOG SPEKTRUMA}

\author{
Arsov Todor \\ Epilepsy Research Centre, University of Melbourne, The Austin Hospital, Melbourne, Australia
}

Klasični GLUT-1 deficit je opisan pre više od 20 godina kao metabolička encefalopatija koja se karakteriše usporenim psihomotornim razvojem, sekundarnom mikrocefalijom, paroksizmalnim neurološkim simptomima (epilepsija) i poremećajima pokreta.
Tokom zadnjih nekoliko decenija opisano je preko 200 slučajeva ovog klasičnog GLUT-1 deficita poznatog kao bolest De Vivo. Biohemijski parametri ove bolesti su nizak nivo glukoze u cerebrospinalnom likvoru, normalni nivo glukoze u krvi i posledično nizak 
odnos glukoze u cerebrospinalnom likvoru prema krvi $(<40-45 \%)$.

Genetska istraživanja su pokazala da su uzrok ove bolesti mutacije u genu SLC2A1 koji kodira transporter za glukozu 1 (GLUT-1) koji pomaže transport glikoze preko hematoencefalne barijere.

Tokom zadnjih nekoliko godina spektar GLUT-1 deficita je proširen na druge retke bolesti

\section{REFERENCES}

1. De Giorgis V, Veggiotti P. GLUT1 deficincy syndrome 2013: Current state of the art.Seizure. 2013; 22(10): 803-11.

2. Pearson ST, Akman C, Hinton JV, Engelstad K, De Vivo CD. Phenotypic Spectrum of Glucose Transporter Type 1 Deficiency Syndrome (Glut1 DS). Curr Neurol Neurosci Rep. 2013; 13(4): 342-51.

3. Pascual JM, Wang D, Lecumberri B, et al. GLUT1 deficiency and other glucose transporter diseases.Eur J Endocrinol.2004; 150(5): 627-33.

4. Rotdtein M, Engelstad K, Yang H, et al. Glut1 Deficiency: Inheritance Pattern Determined by Haploinsufficiency. Ann Neurol. 2010; 68(6): 955-8.

5. Seidner G, Alvarez MG, Yeh JI, et al. GLUT-1 dificiency syndrome caused by haploinsufficiency of the blood-brain barrier hexose carrier. Nat Genet. 1998; 18(2): 188-91.

6. Pascual JM, Ronen GM. Glucose Transporter Type I Deficiency (G1D) at 25 (1990-2015): Presumptions, facts, and the lives of persons with this rare disease. Pediatr Neurol. 2015; 53(5): 379-93.

7. Melnikova AM, Korff CM. Clinical variability of GLUT1DS. Pediatr Neurol Briefs. 2015; 29(2):14.

8. Wang D, Pascual MJ, Yang H, et al. A mouse model for Glut-1 haploinsufficiency. Hum Mol Genet. 2006; 15(7): 1169-79.

9. Strzelczyk A, Bürk K, Oertel WH. Treatment of paroxysmal dyskinesias. Expert Opin Pharmacother. 2011; 12(1): 63-72.

10. Suls A, Dedeken P, Goffin K, et al. Paroxysmal exercise-induced dyskinesia and epilepsy is due to mutations in SLC2A1, encoding the glucose transporter GLUT1. Brain. 2008; 131(Pt7)): 1831-44

11. Weber GY, Storch A, Wuttke VT, et al. GLUT1 mutations are a cause of paroxysmal exertion-induced dyskinesias and induce hemolytic anemia by a cation leak. J Clin Invest. 2008; 118(6): 2157-68.

\section{Correspondence to / Autor za korespondenciju}

Arsov Todor MD, MS, PhD (ANU)

Epilepsy Research Centre, University of Melbourne

The Austin Hospital, Heidelberg VIC 3084, Australia

e-mail: todor.arsov@hotmail.com (paroksizmalna diskinezija pri naporu i absans epilepsije sa ranim početkom), ali i neke češće bolesti, kao što je idiopatska generalizovana epilepsija $(1-2 \%)$.

GLUT-1 deficit je važna patofiziološka osnova ovih bolesti koja treba da se zna i prepozna zato što rana dijagnoza (potpomognuta DNA testiranjem) i terapija (ketogena dijeta) daju bolje rezultate.

12. Schneider AS, Paisan-Ruiz C, Garcia-Gorostiaga I, et al. GLUT1 Gene Mutations Cause Sporadic Paroxysmal Exercise-Induced Dyskinesias. Movement Disorders. 2009; 24(11): 1684-8.

13. Erro R, Sheerin UM, Bhatia PK. Paroxysmal dyskinesias revisited: A review of 500 genetically proven cases and a new classification. Mov Disord. 2014; 29(9): 1108-16.

14. Berkovic SF. Genetics of epilepsy in clinical practice. Epilepsy Curr. 2015; 15(4): 192-6.

15. Suls A, Mullen SA, Weber YG,et al. Early-onset absence epilepsy caused by mutations in the glucose transporter GLUT1. Ann Neurol. 2009; 66(3): 415-9.

16. Arsov T, Mullen AS, Damiano AJ, et al. Early onset absence epilepsy: 1 in 10 cases is caused by GLUT1 deficiency. Epilepsia. 2012; 53(12): 204-7.

17. Arsov T, Mullen AS, Rogers S, et al. Glucose transporter 1 deficiency in the idiopathic generalized epilepsies. Ann Neurol. 2012; 72(5): 807-15.

18. Lebon S, Suarez P, Alija S, et al. When should clinicians search for GLUT1 deficiency syndrome in childhood generalized epilepsies? Eur J Paediatr Neurol. 2015; 19(2): 170-5.

19. Anand G, Padeniya A, Hanrahan D, et al. Milder phenotypes of glucose transporter type 1 deficiency syndrome. Dev Med Chil Neurol. 2011; 53(7): 664-8.

20. Kass RHR, Winesett SP, Bessone SK, Turner Z, Kossoff EH. Use of dietary therapies amongst patients with GLUT1 deficiency syndrome. Seizure. 2016; 35: 83-7.

21. Fujii T, Ito Y, Takahashi S, et al. Outcome of ketogenic diets in GLUT1 deficiency syndrome in Japan: A nationwide survey. Brain Dev. 2016; http://dx.doi.org/10.1016/j.braindev.2016.01.002

22. Akman CI, Yu J, Alter A, Engelstad K, De Vivo CD. Diagnosing glucose transporter 1 deficiency at initial presentation facilitates early treatment. J Pediatric. 2016; 171: 220-6. 